Portland State University

PDXScholar

\title{
The Influence of Bike Lane Buffer Types on Perceived Comfort and Safety of Bicyclists and Potential Bicyclists
}

\author{
Nathan McNeil \\ Portland State University \\ Christopher M. Monsere \\ Portland State University, monsere@pdx.edu \\ Jennifer Dill \\ Portland State University
}

Follow this and additional works at: https://pdxscholar.library.pdx.edu/cengin_fac

Part of the Transportation Engineering Commons

Let us know how access to this document benefits you.

\section{Citation Details}

McNeil, Nathan; Monsere, Christopher M.; and Dill, Jennifer, "The Influence of Bike Lane Buffer Types on Perceived Comfort and Safety of Bicyclists and Potential Bicyclists" (2015). Civil and Environmental Engineering Faculty Publications and Presentations. 221.

https://pdxscholar.library.pdx.edu/cengin_fac/221

This Post-Print is brought to you for free and open access. It has been accepted for inclusion in Civil and Environmental Engineering Faculty Publications and Presentations by an authorized administrator of PDXScholar. Please contact us if we can make this document more accessible: pdxscholar@pdx.edu. 


\section{The Influence of Bike Lane Buffer Types on Perceived Comfort and Safety of Bicyclists and Potential Bicyclists}

Paper \# 15-3701

Nathan McNeil (corresponding author)

Center for Transportation Studies

Nohad A. Toulan School of Urban Studies and Planning

Portland State University

PO Box 751

Portland, OR 97201

503-725-8581 (phone)

503-725-8770 (fax)

nmcneil@pdx.edu

Christopher M. Monsere

Department of Civil \& Environmental Engineering

Portland State University

PO Box 751

Portland, OR 97201

503-725-9746 (phone); 503-725-5950 (fax)

monsere@pdx.edu

Jennifer Dill

Nohad A. Toulan School of Urban Studies and Planning

Portland State University

PO Box 751

Portland, OR 97201

503-725-5173 (phone)

503-725-8770 (fax)

jdill@pdx.edu

32

33

34

35

36

37

Revised: November 15, 2014

Number of Words: 4,939

Number of Figures and Tables: 10 x $250=2,500$

Total Number of Words: 7,439

40 


\section{ABSTRACT}

Buffered and protected bike lanes are increasingly recognized as a valuable tool in enticing 3 potential or wary cyclists to use a bicycle for transportation. These facilities - which provide extra space 4 and (in the case of protected bike lanes) physical separation from motor vehicles - have been studied and 5 are preferred by many bicyclists over traditional bike lanes. There has been little research, however, on 6 the difference between buffer types and how they impact people's sense of the safety and comfort of 7 bicycling. This paper uses data from surveys collected for a multi-city study of newly constructed 8 protected bike lanes to examine the influence of various hypothetical and actual buffered bike lane 9 designs (some with and some without physical protection) from the perspective of current bicyclists $10 \quad(n=1,111)$ and residents living near the new facilities $(n=2,283)$ who could be potential bicyclists.

11 Findings suggest striped or painted buffers offer some level of increased comfort, while buffers with some 12 sort of physical protection, even as minimal as a plastic flexpost, yield significant increases in perceived 13 comfort for potential cyclists with safety concerns (the Interested but Concerned demographic). Among 14 residents living near recently built protected bike lanes, $71 \%$ of all residents and $88 \%$ of the Interested but 15 Concerned indicated that they would be more likely to ride a bicycle if motor vehicles and bicycles were 16 physically separated by a barrier. 
McNeil, Monsere and Dill

\section{INTRODUCTION}

At a basic level, most people will not consider riding a bicycle if they don't believe they have a safe and comfortable place to do so $(1,2)$. Early efforts to dedicate space for bicyclists on roadways resulted in the addition of striped bike lanes which provide a dedicated space for bicycles adjacent to motor vehicle traffic. While research has shown that bicyclists will choose streets with bike lanes over those without (35), there is a growing recognition in the United States that a standard bike lane is sometimes inadequate as a means of establishing a place that many segments of the general population would be willing to ride. In contrast, it is clear that off-street trails or paths offer a comfortable place for most people to bicycle $(1,3)$. Increasingly, designs are seeking to provide additional separation from motor vehicles by providing a "buffer" between a bike lane and other traffic lanes. These buffered bike lanes offer extra separation from other traffic and can provide the space to add physical barriers such as bollards, curbs or planters. While there is growing consensus that the addition of such buffers can increase bicyclists' sense of safety, and the number of on-street bike lanes protected from moving traffic by a buffer has increased considerably (6), there has been little research seeking to differentiate between the effects of various types of buffers and their influence on bicyclist comfort or perception of safety.

A bike lane buffer may be simply paint, in what the National Association of City Transportation Officials (NACTO) terms a "buffered bike lane" in its 2012 Urban Bikeway Design Guide, or it may exist with some form of vertical physical protection in the case of a "cycle track" or protected bike lane (7). There is little published research about the desired type or width of buffers to adequately provide a safe and comfortable riding experience. However, the NACTO design guide suggests a minimum width of 18 inches based on the impracticality of striping a narrower width, and requires diagonal cross-hatching for three foot or greater buffers. In the design of a cycle track, a minimum of a three-foot buffer is suggested "in the absence of a raised median or curb," with the space used to locate bollards or other physical protection (7). The guide also suggests a three foot buffer between parked cars and the bike lane in the case of a parking protected bike lane. A buffer may also exist between a parking strip and a bike lane, which has been shown to encourage bicyclists to ride outside of the "door zone" (8).

A random phone survey of residents of the Portland metro area, a relatively bike-friendly area, found that only $13 \%$ of respondents felt very comfortable bicycling either on streets without bike lanes, or on a busy street with a bike lane. Most of the remaining respondents (56\%) were interested in bicycling, but were not very comfortable in those conditions (3). When asked, most people prefer separated facilities over a striped bike lane or sharing lanes with motor vehicles $(3,9-13)$, and recent research goes further to indicate that perceived risk is lower on separated facilities (13-15). Some research reveals that facility preference may vary among different groups of bicyclists (and non-bicyclists). Sanders (13) asked survey respondents to rate their level of comfort on a number of facilities, including a barrier-separated bike lane with and without parking between the bike lane and the moving traffic lane - interestingly, non-cyclists indicated a greater level of comfort without the parking lane, while weekly or daily cyclists preferred the facilities equally. Some studies have found that more experienced cyclists prefer striped lanes over separate multiuse paths $(4,16-18)$. These differences may be due to factors other than comfort, as paths often require greater deviations from the shortest route or involve mixing with pedestrians (which can slow travel). On the other hand, research has found that women and less-experienced cyclists generally prefer more separated facilities and avoiding high traffic volumes and speeds (12, 19-21).

This paper contributes to the literature by quantifying the influence of buffer type on self-reported comfort levels. To do this, we use data from surveys collected for a multi-city study of newly constructed protected bike lanes (22) to examine the influence of various hypothetical and actual buffered bike lane designs (some with and some without physical protection) from the perspective of current bicyclists and residents who could be potential bicyclists. Not all possible types of buffers (23) are covered and other issues related to barrier types such as maintenance, snow removal, curb access, and durability are not explored in the paper. In the section that follows, the methodology to collect and administer the surveys is described. In the findings section, the analysis of hypothetical buffers comfort is followed by self-reported comfort. Finally, conclusions are presented. 


\section{METHODOLOGY}

2 In the context of this paper, a buffer is considered to be any extra space between a bike lane and a standard traffic lane in an on-street facility. Buffers may simply be delineated by pavement markings (parallel white lines, often with hash marks indicating that the buffer is not a travel space), or may have some aspect of vertical protection or separation (such as a bollard, flexible plastic post (also called a flexpost or safe-hit post), planter box, raised curb, fence, etc.). Buffers may be quite narrow (as little as one to one and a half feet) or wide. They may be characterized as a space where other forms of activity are excluded, as is the case with planters or other treatments that restrict activity by occupying space. Alternatively, other activity may be permitted or designated for a buffer space, such as a parking strip and door zone placed between a bike lane and a standard travel lane (both the parking area and door zone would be considered components of the buffer in this case).

Data used in this paper are from bicyclists intercepted in recently constructed protected bike lanes ("intercept survey") and residents living nearby the new protected bike lanes ("resident survey"). The resident survey ( $n=2,283,23 \%$ of those sent the survey in the mail) provided the perspective of people who live, drive, and walk near the new lanes, as well as residents who bike on the new lanes. The intercept survey ( $n=1,111,33 \%$ of those invited to participate who completed the online survey) focused more on people's experiences riding in the protected lanes. The study facilities included bike lanes with protected buffers separating them from moving traffic lanes in five cities around the United States, as shown in Table 1. The surveys were piloted and refined using a Portland State University (PSU) survey methods class for the resident survey and PSU transportation students for the bicyclist intercept survey. The study was reviewed and approved by PSU's Human Subjects Research Review Committee. The project report provides greater detail on the facilities, methodology, respondent demographics, and survey results (22).

In discussing findings in this paper, respondents of the intercept survey may be referred to as "bicyclists" and respondents of the resident mail-out survey may be referred to as "residents". These categories are not mutually exclusive though, as "bicyclists" could live in the vicinity of the facility, and "residents" could also ride bicycle. However, very few people took both surveys: the resident survey, which launched after the intercept survey, asked respondents if they have taken "a separate online bicyclist survey about these protected bike lanes from us recently"; only 15 respondents, or $0.7 \%$, said they had. 
McNeil, Monsere and Dill

TABLE 1 Facility Characteristics

\begin{tabular}{|c|c|c|c|c|c|c|c|c|}
\hline \multirow[b]{2}{*}{ Facility } & \multicolumn{3}{|c|}{ Austin } & \multicolumn{2}{|c|}{ Chicago } & \multirow{2}{*}{$\begin{array}{c}\text { Portland } \\
\begin{array}{c}\text { Multnomah } \\
\text { Street }\end{array}\end{array}$} & \multirow{2}{*}{$\begin{array}{c}\text { San } \\
\text { Francisco }\end{array}$} & \multirow{2}{*}{$\begin{array}{c}\begin{array}{c}\text { Washingto } \\
\text { n DC }\end{array} \\
\text { L Street }\end{array}$} \\
\hline & $\begin{array}{c}\text { Barton } \\
\text { Springs } \\
\text { Road }\end{array}$ & $\begin{array}{c}\text { Rio } \\
\text { Grande } \\
\text { Street }\end{array}$ & $\begin{array}{c}\text { Blue- } \\
\text { bonnet } \\
\text { Lane }\end{array}$ & $\begin{array}{l}\text { Dearborn } \\
\text { Street }\end{array}$ & $\begin{array}{l}\text { Milwauke } \\
\text { e Avenue }\end{array}$ & & & \\
\hline $\begin{array}{l}\text { Typical Bike } \\
\text { Lane Width } \\
\text { (ft.) }\end{array}$ & 6 & $\begin{array}{c}12\left(6^{\prime}+\right. \\
\left.6^{\prime}\right)\end{array}$ & $10\left(5^{\prime}+5^{\prime}\right)$ & $9\left(5^{\prime}+4^{\prime}\right)$ & 7 & 7 & 7.25 & 8 \\
\hline $\begin{array}{l}\text { One or two } \\
\text { way }\end{array}$ & One-way & Two-way & Two-way & Two-way & $\begin{array}{l}\text { One-way } \\
\text { pair }\end{array}$ & $\begin{array}{l}\text { One-way } \\
\text { pair }\end{array}$ & One-way & One-way \\
\hline $\begin{array}{l}\text { Buffer } \\
\text { Width (ft.) }\end{array}$ & 1.5 & 4 & 4 & 3 & $2-4$ & $3-7$ & 5 & 3 \\
\hline Buffer Type & Flexposts & Flexposts & Flexposts & $\begin{array}{l}\text { Flexposts; } \\
\text { Parking }\end{array}$ & $\begin{array}{l}\text { Parking; } \\
\text { Flexposts; } \\
\text { Paint }\end{array}$ & $\begin{array}{l}\text { Planters; } \\
\text { Flexposts; } \\
\text { Parking }\end{array}$ & Flexposts & Flexposts \\
\hline $\begin{array}{l}\text { Facility } \\
\text { Length } \\
\text { (miles) }\end{array}$ & 0.5 & 0.4 & 0.7 & 1.2 & 0.8 & 0.8 & 0.3 & 1.12 \\
\hline $\mathrm{ADT}$ & $23-28 \mathrm{k}$ & $5 \mathrm{k}$ & $3.5 \mathrm{k}$ & $8-18 k$ & $11 \mathrm{k}$ & $10 \mathrm{k}$ & $10-20 \mathrm{k}$ & $10 \mathrm{k}$ \\
\hline $\begin{array}{l}\text { Approx. } \\
\text { Peak Hour } \\
\text { Bike Count } \\
\end{array}$ & 15 & 70 & 15 & 167 & 425 & 35 & 195 & 115 \\
\hline $\begin{array}{l}\text { Surveys } \\
\text { Conducted }\end{array}$ & $\begin{array}{l}\text { Intercept, } \\
\text { Resident }\end{array}$ & Intercept* & Resident** & $\begin{array}{l}\text { Intercept, } \\
\text { Resident }\end{array}$ & $\begin{array}{l}\text { Intercept, } \\
\text { Resident }\end{array}$ & $\begin{array}{l}\text { Intercept, } \\
\text { Resident }\end{array}$ & $\begin{array}{l}\text { Intercept, } \\
\text { Resident }\end{array}$ & $\begin{array}{l}\text { Intercept, } \\
\text { Resident }\end{array}$ \\
\hline
\end{tabular}

*A resident mail-out survey was not conducted for Rio Grande because the nearby population, dominated by student housing at the University of Texas, had already entered summer break at the time of data collection.

**An intercept survey on Bluebonnet Lane resulted in only two completed responses after only about nine postcards were distributed. This reflected the low use of the facility during the survey period (during the summer, outside of the school year).

\section{Resident Survey}

Paper copies of the resident survey were mailed to up to 2,000 resident addresses within a specific boundary (up to a quarter mile) of each study facility. The size of the boundary around each facility differed based on the density of the surrounding area and the resulting distance needed to achieve an ample sample size. Resident addresses are taken from the Reference USA database accessed through a PSU subscription service. The paper surveys were printed in booklet form and ranged in size from 8-12 pages. Respondents could be entered into a drawing for one of three \$100 Amazon.com gift cards. Survey recipients were given two options for completing the survey. They could fill out the paper copy of the survey and return it in the postage-paid envelope or complete an online version of the questionnaire. Just over a third of respondents (34\%) opted to complete the survey online. The survey asked residents some general questions about their travel behavior, attitudes about bicycling, and potential comfort bicycling different types of facilities. More detailed questions followed about the recently constructed nearby protected bike lane, including questions about how the facility impacted their neighborhood, and about driving, walking and bicycling on the street.

Comparing the overall sample across the cities to Census data, resident survey respondents were older, more likely to be homeowners, and more likely to have at least a four-year college degree. The survey sample contained a slightly higher percentage of respondents identifying as white than comparison tracts (81\% compared to 76\%), and slightly fewer identifying as black, Hispanic/Latino, or Asian (5-6\% compared 8-9\%). Respondents were also more likely to have children in the household and work from home. Although the combined group of respondents was only slightly more likely to be earning $\$ 100,000$ or more, this group was in fact overrepresented in most individual localities. Just over a third of resident respondents $(36 \%)$ had ridden a bicycle on the new facility since it was built (ranging from a low of $28 \%$ for Barton Springs to a high of $46 \%$ for Oak and Fell Streets). To take into account respondents' current 
1 riding behavior and views toward bicycling, residents were broken them down into bicyclist types using an established methodology for grouping people into a "cyclist typology" $(3,24)$. A breakdown of residents found that the respondents consisted of 5\% Strong and Fearless, 27\% Enthused and Confident, $42 \%$ Interested but Concerned, and 25\% No Way No How. One application of the typology is to understand factors that influence the riding decisions of people who might ride a bicycle for transportation, but have concerns that could hold them back - these people would be categorized into the Interested but Concerned group. Of the $64 \%$ of respondents who had not ridden on the facility, $37 \%$ fell into the Interested but Concerned group; of those who had ridden on the facility, $51 \%$ fell into that category.

\section{Intercept Survey}

The intercept survey was designed to catch people riding in the protected bike lanes. Project team members, volunteers or city staff intercepted bicyclists along the study facility and handed them a postcard encouraging them to take an online survey. The postcard included a web address and unique code needed to access the survey. Locations for survey distribution along each facility were typically at places where bicyclists were already required to stop (i.e., stop-controlled or signalized intersections) so that the postcard distributors would not distract the bicyclists and potentially endanger their safety. To reduce the likelihood that an individual received more than one survey postcard, each time period was generally only surveyed once. Similar to the resident survey, respondents to the intercept survey were provided the option to enter a drawing for one of three $\$ 100$ Amazon.com gift cards.

Compared to the resident survey, the intercept survey went into greater depth on bicycle-specific questions relating to comfort on generic facilities and experiences on the recently constructed protected bike lane, and omitted most questions about the impact on the neighborhood, driving, and walking. A breakdown of bicyclists according by the bicyclist typology found that the respondents consisted of $8 \%$ Strong and Fearless bicyclists, 39\% Enthused and Confident, and 53\% Interested but Concerned. Because cyclists were intercepted, no one was typed to No Way No How.

\section{Buffer-Related Survey Questions}

Both surveys asked respondents questions about the specific protected bike lane being studied, as well as questions about generic bike lanes with different types of buffer. Residents and intercepted bicyclists were asked a series of questions relating to how comfortable and safe they thought the protected bike lanes are. Both groups were also asked to rate how comfortable they would be riding a bicycle on a series of hypothetical scenarios, including on a bike path, on a street with no bike lane, a street with a bike lane, and a street with a protected bike lane (see 22). Bicyclists were also asked to rate how comfortable they would feel on a set of generic routes with varying types of buffers, using diagrams of each proposed buffer type (Figure 2). The rating scale presented went from 1 (very uncomfortable) to 6 (very comfortable). Intercepted bicyclists and select residents (those who indicated that they had bicycled on the new protected bike lane) were asked to indicate their comfort on the actual facility using the same scale. On certain facilities with different buffer sections, intercepted bicyclists were asked to about their comfort on the distinct sections. 
McNeil, Monsere and Dill

Whether or not you currently ride a bicycle, please consider how comfortable you would be riding a bicycle in each place:

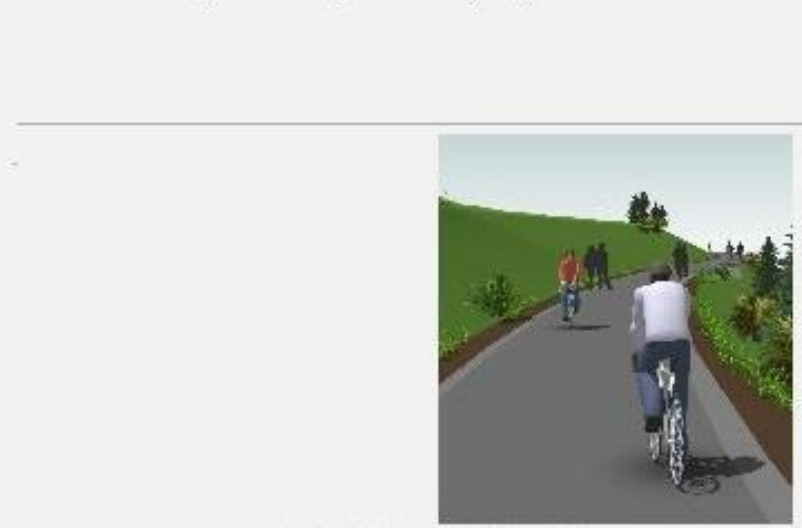

Very

very

Uncomfortable

(1)

(2) (3) (4)

Comfortable

(A) On a path or trail separate from the street

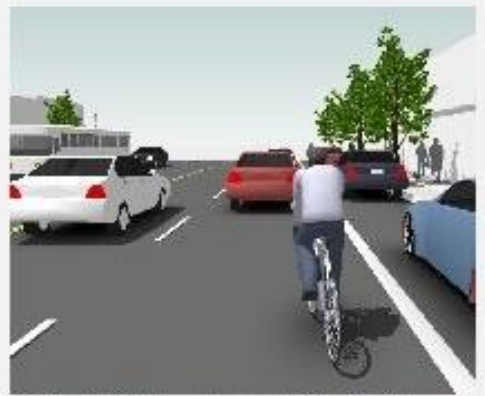

(B) On a commercial street with two lanes of traffic in each direction, with traffic speeds of 35 miles per hour, on-street car parking, and no bike lane

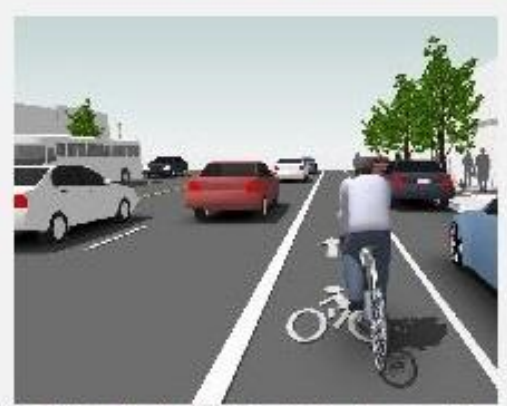

(C) On a similar street to (B), but with a striped bike lane added

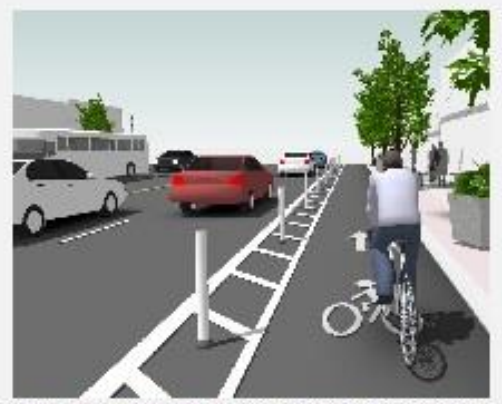

(D) On a similar street to (B), but with a physically separated bike lane

\section{FIGURE 1 Resident and Intercept Survey Generic Facility Comfort Questions}


McNeil, Monsere and Dill

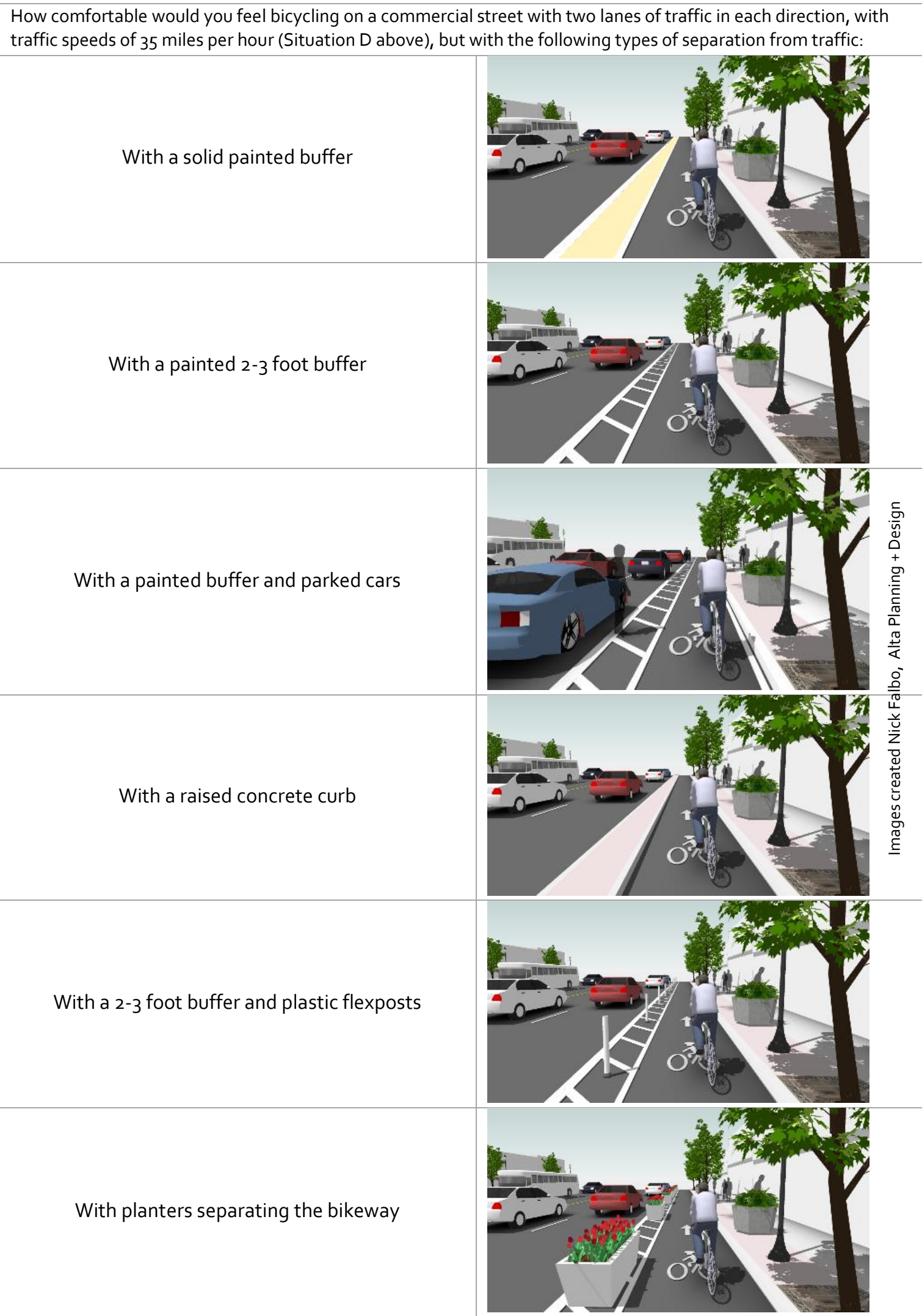




\section{FINDINGS}

\section{Hypothetical Facilities}

Both intercept and resident survey respondents provided stated comfort level information for the four generic facilities shown in Figure 1. Responses to these questions provide some baseline information on the survey respondents' comfort levels absent a buffer separating them from standard traffic lanes (or with a single buffer and flexpost post separated lane). Mean responses on a scale of 1 (very uncomfortable) to 6 (very comfortable), broken down by each facility surveyed, are shown in Table 2 . Each facility surveyed is shown in a column and the scores are rounded to one decimal.

In general, nearly all respondents stated they would be very comfortable (6 on the 1-6 scale) riding on a path or trail separate from the street (Situation A) and uncomfortable ( 1 or 2 on the scale) riding on a commercial street with two lanes of traffic in each direction, with traffic speeds of 35 miles per hour, on-street car parking, and no bike lane (Situation B). While there is minimal difference between the residents and intercepted bicyclists (or between cities/facilities) in comfort levels on a separate path or trail, comfort levels on on-street facilities are consistently lower among residents than intercepted bicyclists. This is undoubtedly because the resident sample includes people who bicycle rarely or not at all, people who our data suggests do not feel comfortable and safe bicycling in most environments.

Most respondents would not be comfortable bicycling on commercial streets without a bike lane, though there are a few minor differences between surveyed facilities: Tukey post-hoc tests revealed that intercepted bicyclists in Washington, DC are statistically significantly more comfortable on streets without bike lanes than intercepted bicyclists in San Francisco (Oak, p<.001), Portland (Multnomah, $\mathrm{p}<.001$ ), and Chicago (Milwaukee, $\mathrm{p}<.01$ and Dearborn, $\mathrm{p}<.05$ ). Austin residents around Barton Springs were statistically significantly less comfortable than Chicago residents near Milwaukee $(\mathrm{p}<.05)$ and San Francisco residents near Oak $(\mathrm{p}<.01)$.

The addition of a bike lane to the commercial street (Situation $\mathrm{C}$ ) brings the mean comfort level up significantly for both bicyclists and residents. Again, Washington DC bicyclist respondents are more comfortable than several other groups, including Chicago (Dearborn, $p<0.01$ ), Portland $(p<.01)$ and San Francisco (Oak p<.05). Resident respondents in Portland and San Francisco were statistically significantly more comfortable than those in Austin around Barton Springs and Chicago around Dearborn (Tukey post-hoc tests, all $\mathrm{p}<.001$ ). The addition of physical separation (Situation D) raises the mean comfort level even higher, solidly into the comfortable half of the scale for both surveyed groups. San Francisco residents were more comfortable than those in Chicago around Milwaukee ( $<<.05)$, while Portland residents were more comfortable than those in Chicago $(\mathrm{p}<.05)$. The differences between the cities in the residents' comfort levels may be due to different levels of bicycling among the residents in those cities, the typical facilities available in those cities, or other demographic or cultural differences.

FIGURE 3 provides a visual representation of the differences between the persons surveyed in each city, including demonstrating that intercepted bicyclists in Washington, DC are more comfortable than other bicyclists on streets with and without bike lanes. 
McNeil, Monsere and Dill

TABLE 2 Mean Stated Comfort on Hypothetical Facilities

\begin{tabular}{|c|c|c|c|c|c|c|c|c|c|}
\hline \multirow{2}{*}{\multicolumn{2}{|c|}{ Hypothetical Facility }} & \multicolumn{2}{|c|}{ Austin* } & \multicolumn{2}{|c|}{ Chicago } & \multirow{3}{*}{$\begin{array}{c}\text { Portland } \\
\text { Mult. } \\
5.7\end{array}$} & \multirow{3}{*}{$\begin{array}{c}\text { SF } \\
\begin{array}{c}\text { Oak / Fell } \\
\text { Streets }\end{array} \\
5.7\end{array}$} & \multirow{3}{*}{$\begin{array}{c}\text { D.C. } \\
\text { L Street } \\
5.7\end{array}$} & \multirow{3}{*}{$\begin{array}{l}\text { All } \\
5.7\end{array}$} \\
\hline & & \multirow{2}{*}{$\begin{array}{c}\begin{array}{c}\text { Barton } \\
\text { Springs }\end{array} \\
5.6\end{array}$} & \multirow{2}{*}{$\begin{array}{c}\begin{array}{c}\text { Rio } \\
\text { Grande }\end{array} \\
5.6\end{array}$} & \multirow{2}{*}{$\frac{\text { Dear. }}{5.8}$} & \multirow{2}{*}{$\frac{\text { Milw. }}{5.7}$} & & & & \\
\hline \multirow{2}{*}{ A) Path or Trail } & Bicyclists & & & & & & & & \\
\hline & Residents & 5.6 & - & 5.5 & 5.5 & 5.5 & 5.6 & 5.5 & 5.6 \\
\hline \multirow{2}{*}{$\begin{array}{l}\text { B) Commercial } \\
\text { Street }\end{array}$} & Bicyclists & 2.5 & 2.5 & 2.5 & 2.5 & 1.9 & 2.1 & 2.9 & $2.4^{\mathrm{a}}$ \\
\hline & Residents & 1.7 & - & 1.8 & 1.9 & 1.8 & 1.9 & 1.8 & $1.8^{\mathrm{b}}$ \\
\hline \multirow{2}{*}{$\begin{array}{l}\text { C) Commercial } \\
\text { Street with Bike } \\
\text { Lane }\end{array}$} & Bicyclists & 4.2 & 4.1 & 4.1 & 4.3 & 4.0 & 4.2 & 4.5 & $4.2^{\mathrm{a}}$ \\
\hline & Residents & 3.3 & - & 3.2 & 3.5 & 3.7 & 3.7 & 3.4 & $3.5^{\mathrm{a}}$ \\
\hline \multirow{2}{*}{$\begin{array}{l}\text { D) Commercial } \\
\text { Street with } \\
\text { Physical } \\
\text { Separation }\end{array}$} & Bicyclists & 5.3 & 5.5 & 5.4 & 5.3 & 5.2 & 5.5 & 5.5 & 5.4 \\
\hline & Residents & 4.6 & - & 4.4 & 4.4 & 4.8 & 4.7 & 4.5 & $4.6^{\mathrm{a}}$ \\
\hline \multirow{2}{*}{$\mathrm{n}$} & Bicyclists & 17 & 42 & 117 & 208 & 108 & 247 & 280 & 1019 \\
\hline & Residents & 519 & $\mathrm{n} / \mathrm{a}$ & 191 & 304 & 468 & 508 & 229 & 2219 \\
\hline
\end{tabular}

a. There was a statistically significant difference between facilities as determined by one-way ANOVA $(p<.001)$

b. There was a statistically significant difference between facilities as determined by one-way ANOVA ( $<<.05)$

*The resident responses under Barton Springs on the hypothetical facilities include resident who responded to the Bluebonnet survey (the survey mail-out area for Bluebonnet was immediately adjacent to the area for Barton Springs, and included questions about the Barton Springs facility) 


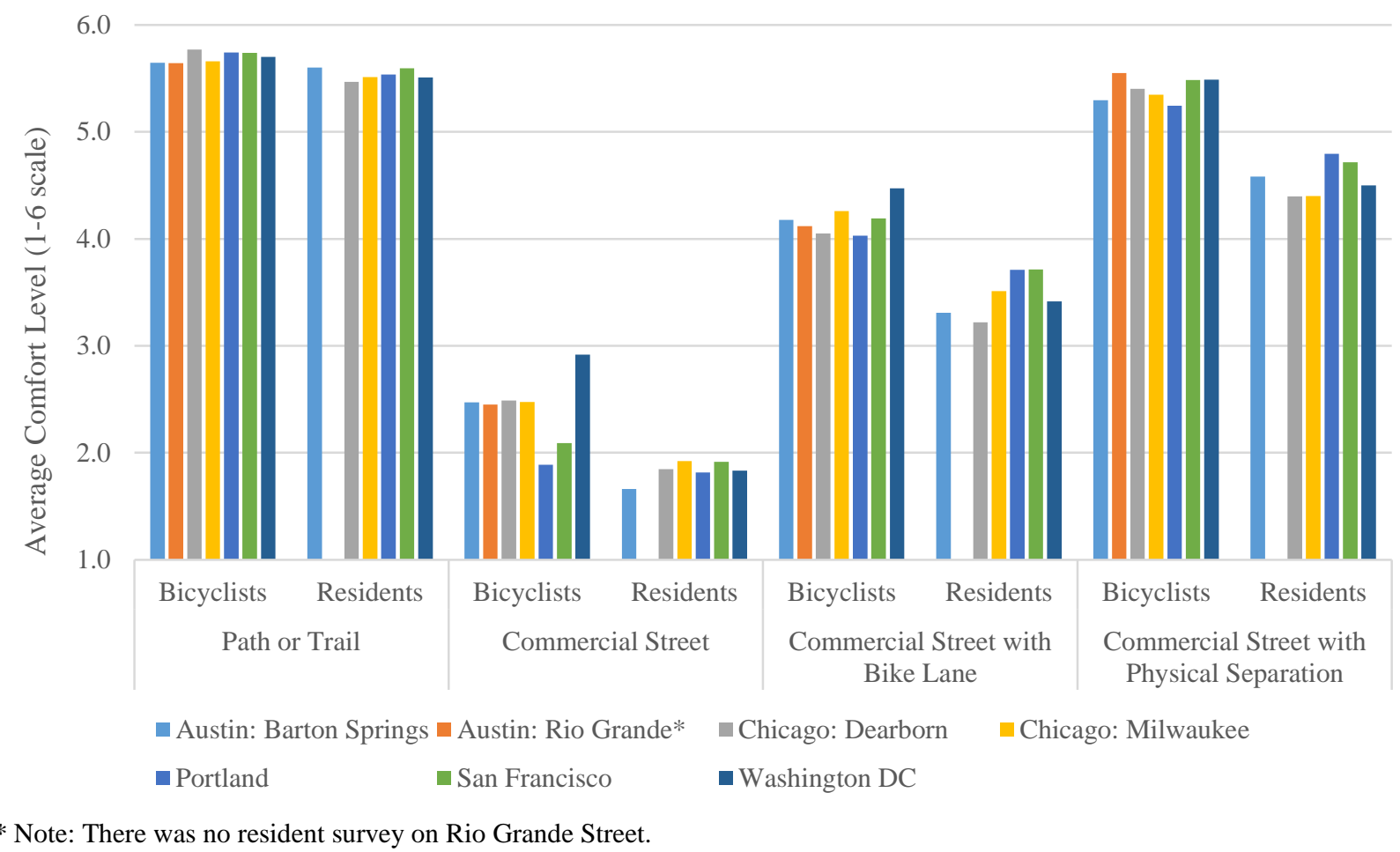

FIGURE 3 Mean Stated Comfort Level on Hypothetical Facilities

Intercepted bicyclists were then asked to use the same scale of 1 (very uncomfortable) to 6 (very comfortable) to indicate their level of comfort on a series of different buffer and separation types (as shown in Figure 2 above). The different buffer types and the mean stated comfort for each are shown in Table 3. The options, shown ranked from least to most comfortable according to mean comfort rating, were presented to survey respondents in an unordered manner; the order of presentation is shown in parenthesis next to each item description in the table. In the table, the types of buffer present on the actual facility on which bicyclists were intercepted have been shaded.

The respondents' comfort ratings of the differing hypothetical buffers are very consistent across the cities and facilities; in fact, the buffers with planters, flexposts, and a concrete curb ranked first, second and third most preferred, respectively, across each of the seven surveys, with the bottom three options showing considerable consistency as well. The buffer types without some type of vertical physical protection, namely the solid painted buffer and the painted 2-3 foot buffer, received the lowest mean comfort rating. Only the buffer consisting of paint and a lane for parked cars had significantly different comfort scores across the cities as revealed by a one-way ANOVA ( $\mathrm{p}<.001)$. Post-hoc Tukey tests revealed respondents on Dearborn and Milwaukee were significantly more comfortable with a parked car buffer than those on Multnomah and Oak, while L Street respondents were also more comfortable than those on Oak. Local experience with a similar type of facility may have influenced respondents perceptions in either a negative manner (as may have been the case in Portland and San Francisco), or in a positive manner (in Chicago and Washington, D.C.). Overall, the comfort rating for the buffer with parking may suggest that, in comparison to the highest rated buffers, parked (or parking vehicles) represent some level of added complication. It could be that parking cars and pedestrian activity from departing passengers influence the perception of comfort.

The most common buffer type used on the actual facilities on which bicyclists were intercepted, the two to three foot buffer with plastic flexposts, is rated very highly despite offering less actual physical protection (i.e. it would not do much to stop a vehicle from entering the bicycle lanes) than two of the 
1 lesser rated facilities (the painted buffer with parked cars and the raised concrete curb). This may suggest

2 that familiarity with the buffer type was a positive experience.

3 TABLE 3 Intercepted Bicyclists Mean Stated Comfort with Hypothetical Buffer Types

\begin{tabular}{l|c|c|c|c|c|c|c|c|c}
\hline \multirow{2}{*}{$\begin{array}{l}\text { Hypothetical Buffer } \\
\text { Type }\end{array}$} & \multicolumn{2}{|c|}{$\begin{array}{c}\text { Austin } \\
\text { Barton } \\
\text { Springs }\end{array}$} & $\begin{array}{c}\text { Rio } \\
\text { Grande }\end{array}$ & Dear. & Milw. & Mult. & $\begin{array}{c}\text { Oak } \\
\text { Fell } \\
\text { Streets }\end{array}$ & $\begin{array}{c}\text { L } \\
\text { Street }\end{array}$ & $\begin{array}{c}\text { All Interested } \\
\text { but } \\
\text { Concerned" } \\
\text { only }\end{array}$ \\
\hline $\begin{array}{l}\text { Solid painted buffer } \\
\text { (5) }\end{array}$ & 4.5 & 4.8 & 4.6 & 4.6 & 4.6 & 4.7 & 4.6 & 4.7 & $4.2^{\mathrm{b}}$ \\
\hline $\begin{array}{l}\text { Painted 2-3 foot buffer } \\
\text { (3) }\end{array}$ & 4.4 & 4.8 & 4.6 & 4.7 & 4.6 & 4.7 & 4.7 & 4.7 & $4.2^{\mathrm{b}}$ \\
\hline $\begin{array}{l}\text { Painted buffer and } \\
\text { parked cars (1) }\end{array}$ & 4.4 & 4.5 & 5.0 & 5.1 & 4.4 & 4.4 & 4.8 & $4.7^{\mathrm{a}}$ & $4.5^{\mathrm{b}}$ \\
\hline $\begin{array}{l}\text { Raised concrete curb } \\
\text { (6) }\end{array}$ & 4.8 & 5.3 & 5.3 & 5.1 & 5.0 & 5.2 & 5.2 & 5.2 & 5.1 \\
\hline $\begin{array}{l}\text { 2-3 foot buffer and } \\
\text { plastic flexposts (2) }\end{array}$ & 5.1 & 5.4 & 5.4 & 5.3 & 5.2 & 5.4 & 5.4 & 5.4 & $5.1^{\mathrm{b}}$ \\
\hline $\begin{array}{l}\text { Planters separating the } \\
\text { bikeway (4) }\end{array}$ & 5.4 & 5.7 & 5.6 & 5.5 & 5.5 & 5.5 & 5.6 & 5.57 & $5.46^{\mathrm{c}}$ \\
\hline $\begin{array}{l}\text { n } \\
\text { n }\end{array}$ & 17 & 42 & 117 & 208 & 108 & 247 & 281 & 1020 & 541 \\
\hline
\end{tabular}

*Shaded cells correspond to buffer type existing on facility where bicyclist was intercepted

a. Mean score is significantly different between facilities as determined by one-way ANOVA ( $\mathrm{p}<.001)$

b. Mean score is significantly different between cyclist types ( $\mathrm{p}<.001)$. Post-hoc Tukey tests show the Interested but Concerned differed from the Strong and Fearless ( $<<.001)$ and Enthused and Confident ( $\mathrm{p}<.001$ )

c. Mean score is significantly different between cyclist types $(\mathrm{p}<.05)$. Post-hoc Tukey tests show the Interested but Concerned differed from the Enthused and Confident ( $\mathrm{p}<.05)$, though not from the Strong and Fearless. Note that results have been rounded to nearest hundredth here to demonstrate the difference.

As shown in the final column of Table 3, bicyclists in the Interested but Concerned category were less comfortable than other cyclist groups in most of the buffer types (the exceptions being the raised concrete curb, where there was no difference, and the planter buffer, where they were only slightly less comfortable than the Enthused and Confident). However, as Figure 4 demonstrates, bicyclists in the Interested but Concerned category did achieve much greater increases in comfort with the buffers over a standard bike lane. The figure shows the change in the overall mean comfort scores for the different bicyclist types in the intercept sample (Strong and Fearless, Enthused and Confident, and Interested but Concerned), compared to a commercial street with a standard striped bike lane (Situation C in Figure 1 and Table 2). For each buffer type, a normalized score of $0 \%$ indicates that the mean comfort level was the same as in a standard bike lane, while a score of $100 \%$ would indicate that the respondents were, on average, twice as comfortable (e.g. an increase of 3 to 6 on our 6 point scale). Those cyclists already falling into the two most comfortable categories realize little change in comfort with several buffer types, and are even slightly less comfortable with a buffer with parked cars. However, the Interested but Concerned group shows an increase in stated comfort of $24 \%$ to $31 \%$ for the painted buffers and buffer with parking, and increase to around 50\% more comfortable for the buffers with a concrete curb, plastic flexposts, or planters. 


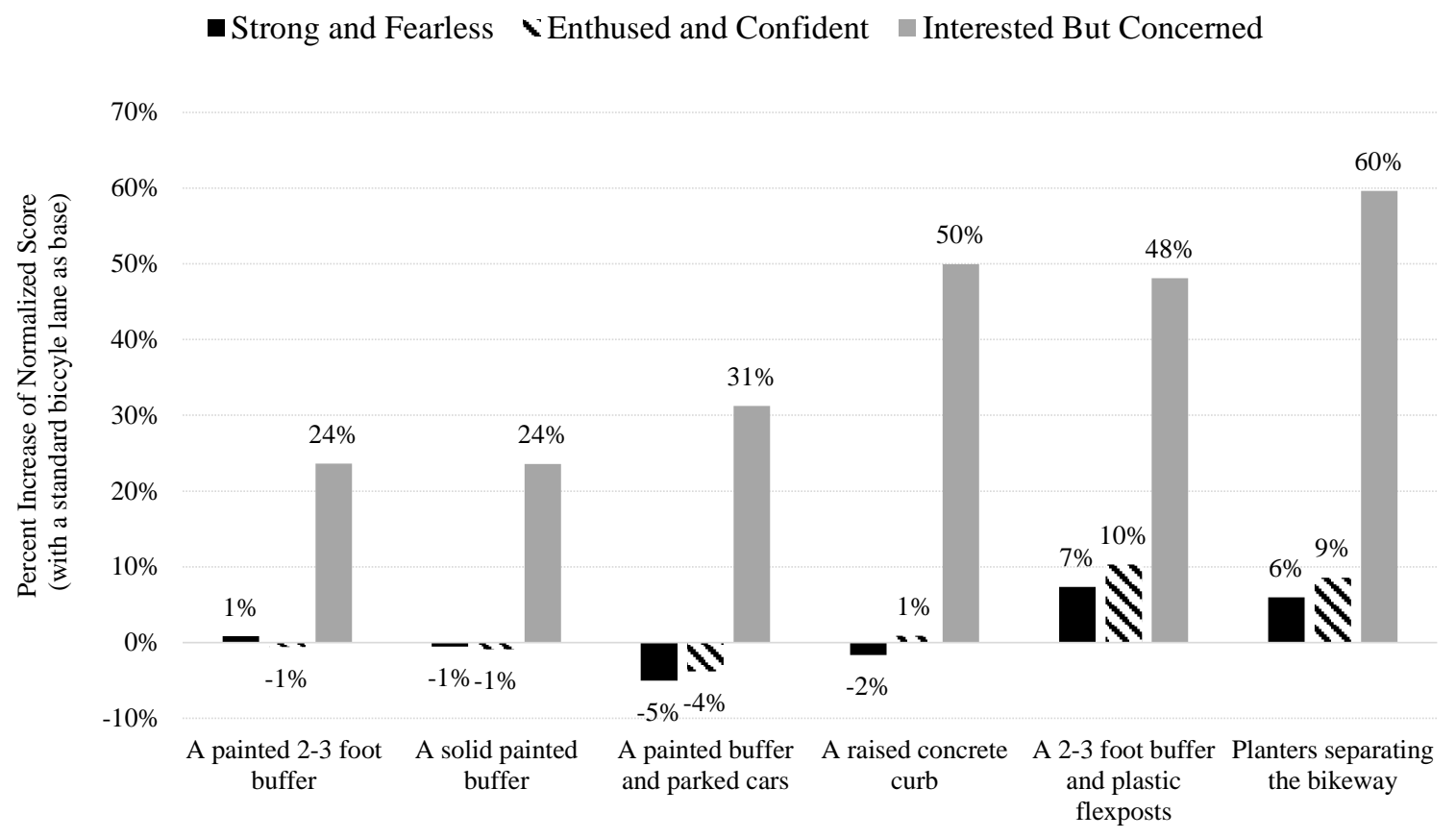

FIGURE 4 Intercepted Bicyclists: Difference in Mean Comfort Score with Hypothetical Buffers from Mean Comfort in a Bike Lane, By Bicyclist Type

\section{Experience on the New Protected Lanes}

Intercepted bicyclists were asked to indicate their comfort level on the same six-point scale for either the overall facility on which they were intercepted, or, in a few cases where the facility had very distinct sections, for specific portions of that facility. Stated comfort levels on actual facilities provide a clearer view of how comfortable bicyclists actually are when riding on a given facility. Mean comfort scores from intercepted bicyclists are shown in Table 4, along with mean comfort scores on roughly equivalent examples from the hypothetical examples. In cases where the actual facility surveyed encompasses multiple hypothetical facilities, an average of the shaded scores shown in Table 3 is shown.

In most cases, the stated comfort in the intercepted facility is considerably lower than the comfort level on hypothetical routes with similar buffer treatments. There are several potential reasons for this discrepancy. First, respondents were asked about their comfort on the actual facility at the beginning of the survey, and asked about the hypothetical buffers later in the survey; they may have adjusted their rating scale as a result of earlier questions (although the survey did allow respondents to go back and change responses). Second, the actual facilities on the ground include features other than the buffer link sections, most obviously intersections that are usually more complicated and potentially less comfortable. Further, the actual roadway conditions, including speed and volume of motor vehicle traffic may differ from respondents' perceptions of the hypothetical facility. Finally, it's also possible that respondents overestimate their expected comfort on hypothetical facilities. 
1 TABLE 4 Intercepted Bicyclists' Stated Comfort and Change in Perceived Comfort on

\begin{tabular}{|c|c|c|c|c|c|c|c|c|c|c|}
\hline \multirow[b]{2}{*}{ City } & \multirow[b]{2}{*}{ Facility and Segment } & \multicolumn{6}{|c|}{ Type of Buffer Present } & \multirow[b]{2}{*}{$\begin{array}{l}\text { Stated } \\
\text { Comfort }\end{array}$} & \multirow[b]{2}{*}{$\begin{array}{l}\text { Hypo. } \\
\text { Comfort * }\end{array}$} & \multirow[b]{2}{*}{$\mathbf{n}$} \\
\hline & & 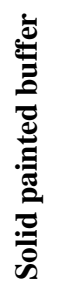 & 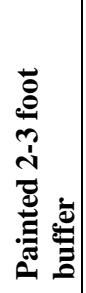 & 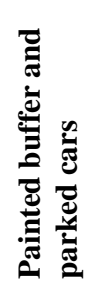 & 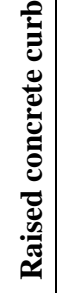 & 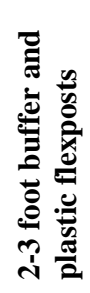 & 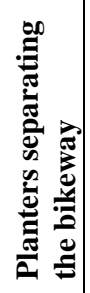 & & & \\
\hline \multirow{3}{*}{ Austin } & Barton Springs & & & & & $\bullet$ & & 4.2 & 5.1 & 18 \\
\hline & $\begin{array}{l}\text { Rio Grande SB contraflow (two- } \\
\text { way) }\end{array}$ & & & & & $\bullet$ & & 5.5 & 5.4 & \multirow{2}{*}{42} \\
\hline & $\begin{array}{l}\text { Rio Grande NB with traffic (two- } \\
\text { way) }\end{array}$ & & & & & $\bullet$ & & 5.3 & 5.4 & \\
\hline \multirow{5}{*}{ Chicago } & Dearborn SB contraflow (two-way) & & & $\bullet$ & & • & & 4.5 & 5.2 & \multirow{2}{*}{123} \\
\hline & Dearborn NB with traffic (two-way) & & & $\bullet$ & & $\bullet$ & & 4.9 & 5.2 & \\
\hline & Milwaukee Striped painted buffer & & • & & & & & 3.8 & 4.7 & \multirow{3}{*}{220} \\
\hline & Milwaukee Buffer with Flexposts & & & & & $\bullet$ & & 4.7 & 5.4 & \\
\hline & Milwaukee Buffer with Parked Cars & & & $\bullet$ & & & & 5.0 & 5.1 & \\
\hline Portland & Multnomah & $\bullet$ & & $\bullet$ & & $\bullet$ & $\bullet$ & 4.6 & 4.9 & 110 \\
\hline \multirow{2}{*}{$\begin{array}{l}\text { San } \\
\text { Francisco }\end{array}$} & Oak Street & & • & & & • & & 4.6 & 5.0 & 247 \\
\hline & Fell Street & & $\bullet$ & & & $\bullet$ & & 4.5 & 5.0 & 247 \\
\hline $\begin{array}{l}\text { Washingto } \\
\text { n D.C. }\end{array}$ & L Street & & & & & $\bullet$ & & 4.5 & 5.4 & 300 \\
\hline $\begin{array}{l}\text { All } \\
\text { Facilities }\end{array}$ & Total & \multicolumn{6}{|c|}{$\mathrm{n} / \mathrm{a}$} & 4.6 & 5.2 & $\begin{array}{c}106 \\
0\end{array}$ \\
\hline
\end{tabular}

*Hypothetical comfort scores are derived from the participants mean comfort scores on roughly equivalent hypothetical buffer scenarios presented in Table 3, as marked by the columns under "Type of Buffer Present."

To get at the effect of the buffer specifically on the perceived changes for bicyclists, respondents were asked to indicate their level of agreement with a series of questions about the facility, from strongly disagree (1), somewhat disagree (2), somewhat agree (3), and strongly agree (4). Statements included "the buffer makes me feel safe" (with some facilities' buffers further broken down into separate statements for separate buffer sections), and questions about the effectiveness of the buffer at separating and protecting the bicyclist. Table 5 shows mean agreement and percentage of respondents indicating they agree 
somewhat or strongly. While strong majorities indicate the buffer makes them feel safe, effectively separates bikes from cars, protects bikes from cars, and effectively separates bicyclists from pedestrians, there are a few outliers: The intercepted bicyclists in Washington D.C. were a little less likely to agree that the buffer effectively separated bikes from cars, though $81 \%$ did agree. The bicyclists in that city were also more likely in most cases to indicate that they "often" encounter parked cars, cars loading or unloading passengers, delivery vehicles, and taxis in the bike lane (four separate questions). On Barton Springs Road, one in three respondents disagreed that the buffer does a good job at protecting bikes from cars, though the sample size is too low to draw firm conclusions. On Dearborn Street, nearly half of the intercepted bicyclists felt that the facility did not effectively separate bicyclists from pedestrians.

TABLE 5 Intercepted Bicyclists: Agreement on Buffer Effectiveness

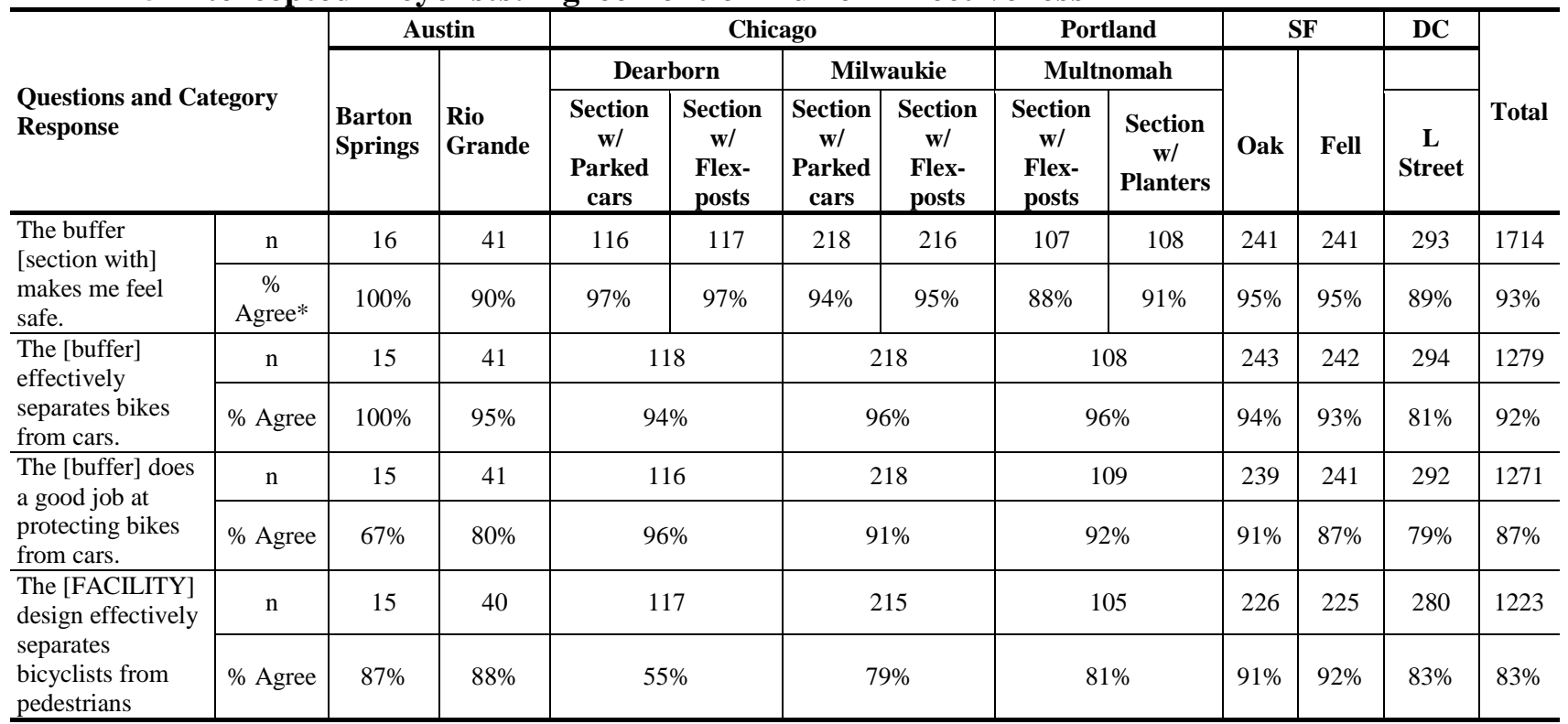

* The "\% Agree" rows are the percentage of respondents indicating they "somewhat agree" or "strongly agree" with the statement.

\section{Residents' Perceptions of Actual Facilities}

The perceptions of area residents to the impact of a new bicycle facility may play an important factor in the success of the facility in encouraging new ridership. Table 6 provides residents' responses to survey questions pertaining to the impact of buffers. Around $71 \%$ of all residents indicated they agree somewhat or strongly that they would be more likely to ride a bicycle if motor vehicles and bicycles were physically separated by a barrier. Eight out of nine in the Interested but Concerned group agreed. Although around half of the resident respondents in the Strong and Fearless and No Way No How groups disagreed with this statement, that result is expected given that the former are likely comfortable enough to be riding already, and the latter are not going to be swayed no matter what. Similar numbers of both the overall resident sample and of the Interested but Concerned group felt that the new facility resulted in an increase in the safety of bicycling on that street, likely because they also agreed that the buffer did a good job of separating (85\% agreement overall) and protecting (82\% agreement overall) bikes from cars.

On the only facility that included planters separating the bike lane from standard traffic lanes, Portland residents had a higher amount of strong agreement with the effectiveness of the buffer, both in separating bikes from cars (57\% strongly agreed in Portland compared to $46 \%$ overall) and in protecting bikes from cars (50\% strongly agreed in Portland compared to $39 \%$ overall). This may suggest that the planter buffer is perceived as better at separating bikes from cars among residents in general (whereas intercepted bicyclists rated the buffer with planters about equally to the buffers with flexposts and with a concrete curb). 
1 TABLE 6 Resident Perceptions of Protected Bike Lanes and Buffers

\begin{tabular}{|c|c|c|c|c|c|c|}
\hline Question & Response Category & $\begin{array}{l}\text { "Strong } \\
\text { and } \\
\text { Fearless" }\end{array}$ & $\begin{array}{l}\text { "Enthused } \\
\text { and } \\
\text { Confident" }\end{array}$ & $\begin{array}{l}\text { "Interested } \\
\text { But } \\
\text { Concerned" }\end{array}$ & $\begin{array}{l}\text { "No Way } \\
\text { No How" }\end{array}$ & Total \\
\hline \multirow{4}{*}{$\begin{array}{l}\text { I would be more likely to } \\
\text { ride a bicycle if motor } \\
\text { vehicles and bicycles were } \\
\text { physically separated by a } \\
\text { barrier. }\end{array}$} & $\mathrm{n}$ & 86 & 474 & 837 & 430 & 1827 \\
\hline & $\%$ Disagree & $49 \%$ & $29 \%$ & $12 \%$ & $57 \%$ & $29 \%$ \\
\hline & $\%$ Somewhat Agree & $23 \%$ & $31 \%$ & $27 \%$ & $24 \%$ & $27 \%$ \\
\hline & $\%$ Strongly Agree & $28 \%$ & $40 \%$ & $61 \%$ & $19 \%$ & $44 \%$ \\
\hline \multirow{4}{*}{$\begin{array}{l}\text { Because of the protected } \\
\text { bike lanes, the safety of } \\
\text { BICYCLING on the street } \\
\text { has . . }\end{array}$} & $\mathrm{n}$ & 98 & 520 & 812 & 482 & 1912 \\
\hline & $\begin{array}{l}\% \text { Decreased, Not } \\
\text { Changed, or No Opinion }\end{array}$ & $20 \%$ & $14 \%$ & $13 \%$ & $43 \%$ & $21 \%$ \\
\hline & $\%$ Increased Somewhat & $33 \%$ & $26 \%$ & $36 \%$ & $38 \%$ & $34 \%$ \\
\hline & $\%$ Increased A Lot & $47 \%$ & $60 \%$ & $52 \%$ & $19 \%$ & $46 \%$ \\
\hline \multirow{4}{*}{$\begin{array}{l}\text { The buffer effectively } \\
\text { separates bikes from cars. }\end{array}$} & $\mathrm{n}$ & 96 & 503 & 802 & 465 & 1866 \\
\hline & $\%$ Disagree & $14 \%$ & $5 \%$ & $12 \%$ & $29 \%$ & $14 \%$ \\
\hline & $\%$ Somewhat Agree & $38 \%$ & $32 \%$ & $41 \%$ & $41 \%$ & $38 \%$ \\
\hline & $\%$ Strongly Agree & $49 \%$ & $63 \%$ & $47 \%$ & $30 \%$ & $47 \%$ \\
\hline \multirow{4}{*}{$\begin{array}{l}\text { The buffer does a good job } \\
\text { at protecting bikes from } \\
\text { cars. }\end{array}$} & $\mathrm{n}$ & 93 & 496 & 787 & 450 & 1826 \\
\hline & $\%$ Disagree & $17 \%$ & $7 \%$ & $15 \%$ & $33 \%$ & $17 \%$ \\
\hline & $\%$ Somewhat Agree & $40 \%$ & $37 \%$ & $48 \%$ & $42 \%$ & $43 \%$ \\
\hline & $\%$ Strongly Agree & $43 \%$ & $56 \%$ & $38 \%$ & $24 \%$ & $40 \%$ \\
\hline \multirow{4}{*}{$\begin{array}{l}\text { The protected bike lanes } \\
\text { effectively separate } \\
\text { bicyclists from pedestrians. }\end{array}$} & $\mathrm{n}$ & 98 & 517 & 813 & 480 & 1908 \\
\hline & $\%$ Disagree or no opinion & $43 \%$ & $23 \%$ & $29 \%$ & $51 \%$ & $34 \%$ \\
\hline & $\%$ Somewhat Agree & $20 \%$ & $36 \%$ & $39 \%$ & $33 \%$ & $36 \%$ \\
\hline & $\%$ Strongly Agree & $37 \%$ & $41 \%$ & $32 \%$ & $16 \%$ & $31 \%$ \\
\hline
\end{tabular}

\section{CONCLUSIONS}

4 This study was limited in that the primary objective of the survey was not specifically to evaluate the comfort of different types of buffers, but was to more broadly understand how well certain specific protected bike lanes were functioning. Therefore, there was limited space to inquire about hypothetical buffers, and a limited palate of actually implemented buffer types included. Future work should focus on buffer types to allow for greater comparability of an array of different buffers, and to include other types of questions such as a ranking of buffer types. A survey specifically designed to capture preferences could use more robust survey designs.

The findings suggest that, in general, bike lanes with the addition of an extra buffered space can increase the perceived safety and comfort of bicycling for both current and potential bicyclists, which in turn would make people more likely to ride a bicycle for transportation. Overall, both current bicyclists and residents (which includes both people who do and do not bicycle) indicated that they would feel comfortable riding on a busy commercial street if there was a bike lane with physical protection. In contrast, current bicyclists were also fairly comfortable on streets with standard striped bike lanes, while residents were not.

Among current bicyclists, the presence of some type of vertical physical separation (compared to hypothetical situations with buffers consisting only of paint) makes a positive difference in improving sense of comfort, with a particularly large increase in stated comfort for the Interested but Concerned 
group. However, the physical protection included in the buffer may achieve much of the beneficial effect using relatively affordable and available materials: the high stated comfort levels of bicyclists to 2-3' painted buffers with plastic flexposts suggests that simple delineators may be enough to substantially improve the comfort level of a buffer for many existing bicyclists. Because we did not ask the residents, which include people who currently do not bicycle, questions about the different buffer types, it is unclear whether the type of physical separation would have a major effect on attracting new bicyclists. Other issues related to maintenance and operations need to be considered in buffer selection, which this paper does not address.

Nearly all the intercepted bicyclists agree that the buffer makes them feel safer (compared to the previous facility). This is the case with painted buffers with plastic flexposts, as well as the lanes that had parked cars or planters in the buffers. With a few exceptions, bicyclists also overwhelmingly agree that the installed buffers are effective at separating cars from bicycles and protecting bicycles from cars. Stated comfort on recently ridden facilities suggests that the high expected levels of comfort based on hypothetical buffers are not quite achieved in reality - this may be due to lesser comfort at intersections, which is not taken into account in the hypothetical situations, or other factors.

Finally, residents expressed strong beliefs that the buffers effectively separate and protect bikes from cars, and as a result, the safety of bicycling on the routes has increased. Nearly three-quarters of all residents indicated that they would be more likely to ride a bicycle with physically separated bike lanes, with fully $88 \%$ of the Interested but Concerned group agreeing. Findings also suggest that Portland residents felt a stronger sense of separation and protection was achieved by the buffer with a planter over residents surveyed about facilities with buffers containing flexposts or parking strip.

\section{ACKNOWLEDGEMENTS}

This research was funded by the National Institute for Transportation and Communities (NITC), a U.S. Department of Transportation university transportation center, People for Bikes (formerly Bikes Belong) and the Summit Foundation. This research could not have been conducted without the significant participation of our city partners. These individuals provided data, design plans, conducted numerous reviews, and hosted our field visits: Mike Amsden (CDOT), David Smith (CDOT), Jim Sebastian (DDOT), Mike Goodno (DDOT), Roger Geller (PBOT), Rob Burchfield (PBOT), Ross Swanson (PBOT), Wendy Cawley (PBOT), Lindsay Walker (Lloyd District TMA), Seleta Reynolds (SFMTA), Miriam Sorell (SFMTA), Annick Beaudet (Austin), Nathan Wilkes (Austin), Aleksiina Chapman (Austin). We acknowledge the efforts of the following Portland State University Students who assisted in survey mailing and video processing: Chase Ballew, Dan Stumpf, Dan Mercer, Lisa Okomoto, Allison Duncan, and Belinda Judelman. We also acknowledge the volunteers in each city that helped conduct the bicycle intercept survey. Joe Gilpin and Matt Berkow (Alta Planning + Design) and Jamie Parks provided input as project team members.

\section{REFERENCES}

1. Dill, J. and Voros, K., Factors Affecting Bicycling Demand: Initial Survey Findings from the Portland, Oregon, Region. In Transportation Research Record: Journal of the Transportation Research Board, No. 2031, Transportation Research Board of the National Academies, Washington, D.C., 2007, 9-17.

2. Winters, M., Davidson, G., Kao, D. and Teschke, K. Motivators and deterrents of bicycling: comparing influences on decisions to ride. Transportation. Vol. 38, No. 1, 2010, 1-16.

3. Dill, J. and N. McNeil. Four Types of Cyclists? Examination of Typology for Better Understanding of Bicycling Behavior and Potential. In Transportation Research Record: Journal of the Transportation Research Board, No. 2387, Transportation Research Board of the National Academies, Washington, D.C., 2013, 129-138. 
4. Tilahun, N.Y., D.M. Levinson, K.J. Krizek. Trails, Lanes, or Traffic: Valuing Bicycle Facilities with an Adaptive Stated Preference Survey, Transportation Research Part A: Policy and Practice. Vol. 41, No. 4, 2007, 287-301.

5. Broach, J., J. Dill, and J. Gliebe, "Where Do Cyclists' Ride? A Route Choice Model Developed with Revealed Preference GPS Data," Transportation Research-Part A, 46: 1730-1740, 2012.

6. Inventory of Protected Bike Lanes. People for Bikes. Accessed online July 302014 at http://www.peopleforbikes.org/green-lane-project/pages/inventory-of-protected-bike-lanes.

7. Urban Bikeway Design Guide. National Association of City Transportation Officials, New York. http://nacto.org/cities-for-cycling/design-guide/. Accessed July 2014.

8. Torbic, D.J., K.M. Bauer, C.A. Fees, D.W. Harwood, R. Van Houten, J. LaPlante, and N. Roseberry. Recommended Bicycle Lane Widths for Various Roadways Characteristics. National Cooperative Highway Research Program Report 766, Transportation Research Board of the National Academies, Washington, D.C., 2014.

9. Shafizadeh, K. and D. Niemeier. Bicycle Journey-to-Work: Travel Behavior Characteristics and Spatial Analysis. In Transportation Research Record: Journal of the Transportation Research Board, No. 1578, Transportation Research Board of the National Academies, Washington, D.C., 1997, 84-90.

10. Rose, G. and H. Marfurt. Travel Behaviour Change Impacts of a Major Ride to Work Day Event. Transportation Research Part A: Policy and Practice. Vol. 41, No. 4, 2007, pp. 351-364.

11. Emond, C. R., W. Tang, and S. L. Handy. Explaining Gender Difference in Bicycling Behavior. In Transportation Research Record: Journal of the Transportation Research Board, No. 2125, Transportation Research Board of the National Academies, Washington, D.C., 2009, 16-25.

12. Winters, M., and K. Teschke. Route Preferences Among Adults in the Near Market for Bicycling: Findings of the Cycling in Cities Study. American Journal of Health Promotion, Vol. 25, No. 1, 2010, pp. 40-47.

13. Sanders, R. Examining the Cycle: How Perceived and Actual Bicycling Risk Influence Cycling Frequency, Roadway Design Preferences, and Support for Cycling Among Bay Area Residents, 2013, University of California, Berkeley, Berkeley, CA, 218 pp.

14. Monsere, C., N. McNeil, and J. Dill. Multiuser Perspectives on Separated, On-Street Bicycle Infrastructure. In Transportation Research Record: Journal of the Transportation Research Board, No. 2314, Transportation Research Board of the National Academies, Washington, D.C., 2012, 22-30.

15. Goodno, M., N. McNeil, J. Parks, and S. Dock. Evaluation of Innovative Bicycle Facilities in Washington, D.C. In Transportation Research Record: Journal of the Transportation Research Board, No. 2387, Transportation Research Board of the National Academies, Washington, D.C., 2013, 139-148.

16. Stinson, M. and C. Bhat. Commuter Bicyclist Route Choice: Analysis using a Stated Preference Survey. In Transportation Research Record: Journal of the Transportation Research Board, No. 1828, Transportation Research Board of the National Academies, Washington, D.C., 2003, 107115.

17. Hunt, J. D., and J. E. Abraham. Influences on Bicycle Use. Transportation, Vol. 34, No. 4, 2007, pp. 453-470.

18. Akar, G., and K. J. Clifton. The Influence of Individual Perceptions and Bicycle Infrastructure on the Decision to Bike. In Transportation Research Record: Journal of the Transportation Research Board, No. 2140, Transportation Research Board of the National Academies, Washington, D.C., 2009, 165-172.

19. Jackson, M. E., and E. O. Ruehr. Let the People Be Heard: San Diego County Bicycle Use and Attitude Survey. In Transportation Research Record: Journal of the Transportation Research Board, No. 1636, Transportation Research Board of the National Academies, Washington, D.C., 1998, 8-12. 
20. Garrard, J., G. Rose, and S. Lo. Promoting Transportation Cycling for Women: The Role of Bicycle Infrastructure. Preventive Medicine, Vol. 46, No. 1, 2008, pp. 55-59.

21. Krizek, K. J., P. J. Johnson, and N. Tilahun. Conference Proceedings 35: Gender Differences in Bicycling Behavior and Facility Preferences. Transportation Research Board of the National Academies, Washington, D.C., 2005, pp. 31-40.

22. Monsere, C., J. Dill, N. McNeil, K. Clifton, N. Foster, and T. Goddard. Lessons from the Green Lanes: Evaluating Protected Bike Lanes in the U.S. National Institute for Transportation and Communities, Portland, OR, 2014.

23. Anderson, M. "Wonktastic Chart Rates 15 Different Ways To Protect Bike Lanes" Available at http://www.peopleforbikes.org/blog/entry/wonktastic-chart-rates-15-different-ways-to-protectbike-lanes. Accessed July 31, 2014.

24. Geller, R. Four Types of Cyclists. Portland Bureau of Transportation, Portland, Ore., 2006. Available at http://www.portlandoregon.gov/transportation/article/264746. Accessed April 18, 2014. 